\title{
UNLEASHING SUSTAINABILITY TRANSFORMATIONS \\ THROUGH ROBUST ACTION
}

\author{
Dror Etzion \\ Desautels Faculty of Management \\ McGill University \\ 1001 Sherbrooke Street West \\ Montreal, Quebec H3A 1G5 \\ dror.etzion@mcgill.ca
}

Joel Gehman

Alberta School of Business

University of Alberta

3-23 Business Building

Edmonton, Alberta T6G 2R6

jgehman@ualberta.ca

Fabrizio Ferraro

IESE Business School

Av. Pearson 21

Barcelona, Spain, 08034

fferraro@iese.edu

\author{
Miron Avidan \\ Desautels Faculty of Management \\ McGill University \\ 1001 Sherbrooke Street West \\ Montreal, Quebec H3A 1G5 \\ miron.avidan@mail.mcgill.ca
}

June 18, 2015

Forthcoming in the Journal of Cleaner Production 


\title{
UNLEASHING SUSTAINABILITY TRANSFORMATIONS \\ THROUGH ROBUST ACTION
}

\begin{abstract}
Shifting to dramatically more sustainable systems is an unconventional or wicked problem, encompassing multiple actors, disciplines, and values. Yet to date, sustainability initiatives have been tackled primarily by means of conventional managerial approaches. We contend that these approaches are ill-suited for achieving sustainability transformations. We propose an alternative approach founded upon the sociological concept of robust action. In robust action, leaders embrace ambiguity (rather than striving for clarity), focus on short-term accomplishments (rather than long-term goals), and are satisfied with oblique movement (rather than linear progress). We elaborate on three robust strategies - participatory architecture, multivocal inscription and distributed experimentation - and investigate their effectiveness in three sustainability related contexts: wind power, sustainability reporting and microcredit. We conclude by discussing the applicability of robust action to other contexts where systemic sustainability transformation is desired, and the complementarities between robust action and other forms of leadership towards sustainability.
\end{abstract}

\section{Highlights}

- Conventional management approaches are unsuited to sustainability challenges.

- We elaborate an alternative robust action approach.

- We analyze three cases: wind power; microcredit; sustainability reporting.

- We compare robust action with other sustainability frameworks.

Keywords: sustainability; robust action; wind power; sustainability reporting; microcredit 


\section{Introduction}

Sustainability, commonly defined as meeting the needs of the present without compromising the ability of future generations to meet their needs (WCED, 1987), is increasingly a cardinal concern for many stakeholders (Markard, Raven, \& Truffer, 2012). Governments and international organizations have long been interested in sustainability, resulting in significant investments in poverty alleviation, economic development and environmental protection efforts, among others. More recently, individuals, corporations, nonprofits and other actors also have become involved in such efforts. This engagement has fostered a range of activities, including social entrepreneurship (e.g. Grameen Bank, Kickstarter), standard setting initiatives (e.g. Global Reporting Initiative, LEED), institutional redesign (e.g. B Lab, $1 \%$ for the Planet), and private transnational governance initiatives (e.g. Forest Stewardship Council, Fair Labor Association), among others. Speaking to this diversity, Paul Hawken, in his book Blessed Unrest, observed that sustainability concerns have given rise to the largest movement in world history, involving on the order of one million organizations globally (Hawken, 2007).

At the same time, the organizations that comprise this movement, which typically have little formal power, authority or resources, are confronted with numerous technical, relational and temporal challenges related to sustainability (Garud \& Gehman, 2012). Nonetheless, their relatively small-scale localized efforts have in some cases generated grand-scale outcomes, several of which have been well publicized and justifiably lauded (e.g. Miller, Grimes, McMullen, \& Vogus, 2012; Prahalad, 2005; Yunus, 1999). Clearly, there is much to be learned by studying individual success stories. Moreover, with the growing amount of studies and evidence already amassed, consolidation of existing cases into a cohesive and coherent 
leadership framework is not only the next logical step but a worthy objective of research (Colquitt \& George, 2011; George, 2014; Margolis \& Walsh, 2003).

In this paper, then, we draw upon prior research in a variety of settings and contexts to describe and substantiate a model of leadership by means of which individual organizations can foster grand-scale sustainability transformations. We first motivate our departure from orthodoxy by observing that "unconventional" thinking appears central to many of the success stories of sustainability transformations. We then build upon recent theoretical work that has proposed "robust action" as a viable approach to tackling grand challenges (Ferraro, Etzion, \& Gehman, 2015), while noting the relative paucity of empirical analysis in that study. Here, we seek to provide initial evidence of the viability of the robust action approach by extending and elaborating three key robust strategies - participatory architecture, multivocal inscription and distributed experimentation - and then investigating their application in three exemplary case studies: wind power, sustainability reporting and microcredit.

Our study employs an exploratory (rather than hypothetico-deductive) approach. We proceed by analyzing, through the lens of robust action, these three well-known success stories in order to discern the extent to which leadership activities consistent with robust action were pursued. Through a theoretically grounded re-examination (e.g., Allison, 1972) of existing empirical cases, our analysis underscores the possibility that robust action can be effective for organizational actors engaged in systemic sustainability transformations. We conclude by examining some contingencies governing the likely effectiveness of robust action, and the extent to which it might complement other sustainability approaches, namely common pool resource management (Dietz, Ostrom, \& Stern, 2003; Ostrom, 1990) and the framework for strategic sustainable development (Ny et al., 2006; Robèrt et al., 2002). 


\section{Conventional Management and Its Limitations}

Conventional management is often construed as a relatively linear and orderly activity, typically conducted by a "rational" planner who strives to attain well-defined targets or solutions. Established in the mid-twentieth century as a discipline through the pioneering work of Herbert Simon, Igor Ansoff and others (Andrews, 1971; Ansoff, 1965; Chandler, 1962; Simon, 1947), advocates of conventional management have developed and refined a methodical, well-defined process through which organizational goals can be attained. A recent exemplar of conventional management is the Balanced Scorecard:

A company begins by developing a strategy statement and then translates it into the specific objectives and initiatives of a strategic plan. Using the strategic plan as a guide, the company maps out the operational plans and resources needed to achieve its objectives. As managers execute the strategic and operational plans, they continually monitor and learn from internal results and external data on competitors and the business environment to see if the strategy is succeeding. Finally, they periodically reassess the strategy, updating it if they learn that the assumptions underlying it are outof-date or faulty, starting another loop around the system. (Kaplan \& Norton, 2008: 65)

This managerial approach, which proceeds in an orderly manner from planning to acquisition of resources to execution while monitoring, learning and improving is a curricular mainstay among business schools and management faculties worldwide, as well as countless corporations and other entities (Cabantous \& Gond, 2011; March, 2011; Mintzberg, 2004).

Many scholars have, however, noted the limitations of these approaches (e.g. Rittel \& Webber, 1973). A first set of objections arises from simple observation: empirically, managers seldom resolve problems as prescribed (Mintzberg, 1973). Planning and management, as enacted by managers, is, in reality, more likely to be emergent, as opposed to deliberate, occurring alongside or even subsequent to action, as opposed to preceding it (Cohen, March, \& Olsen, 1972; Mintzberg, 1987). A second set of objections suggests that rational planning is too narrowly prescribed, overly oriented towards exploitation of existing competencies rather than 
exploration of new innovations (March, 1991). Indeed, innovation is difficult to generate hierarchically; in organizational contexts it tends to emerge at the nexus of non-hierarchical links of multiple organizational types employing diverse populations of experts (Garud, Tuertscher, \& Van de Ven, 2013; Powell, Koput, \& Smith-Doerr, 1996), making its management via conventional paradigms extremely challenging. Overarching these knowledge and control limitations, and perhaps even more problematic, is the tendency of managerial attention to be directed towards near term objectives and narrow incentive structures rather than towards multifaceted goals (Dobbin \& Jung, 2010; Reich, 2008; Slawinski \& Bansal, 2015).

In short, organizations are too complex, contingencies too numerous, and unexpected developments too frequent for one or a small number of persons to plan and manage with a clear grasp of causes and effects. When managers grapple with large, intricate and long-term scenarios, their planning capabilities become increasingly limited:

Would Boeing really have benefited from careful analyses in the mid-1960s of the prospective return on investment from development of the 747? An analyst would have had to anticipate the oil shock, the globalisation of world markets and the development of the aviation industry through to the end of the century. Anyone who has built models of these kinds, or scrutinised them carefully, knows that the range of possible assumptions is always wide enough to allow the analyst to come up with whatever answer the person commissioning the assessment wants to hear. (Kay, 2004)

The inevitable inability to plan and manage "conventionally" for such long-term scenarios is even more apparent when one considers the pursuit of sustainability. Large scale sustainability issues like poverty, illiteracy and social justice as well as climate change, biodiversity loss and other forms of environmental degradation are essentially wicked problems, in which "one cannot understand the problem without knowing about its context; one cannot meaningfully search for information without the orientation of a solution concept; one cannot first understand, then solve" (Rittel \& Webber, 1973: 162). These problems are vaguely defined, rather than specific; goal attainment cannot be unambiguously articulated; interdependencies are 
the rule rather than the exception; and, span of formal control is lesser than the scope of the challenge (Cash et al., 2006).

Conventional management is largely ineffective for resolving wicked problems not merely because the sheer amount of data that needs to be processed and analyzed is overwhelming, but also because trade-offs are inevitable, preferences and values are unknown and often conflicting, stakeholders appear and disappear over time, boundaries are unclear, hierarchy is absent, more than one "planner" is attempting to solve "the problem," and activities designed to resolve the problem modify the problem itself (Dietz et al., 2003; Lindblom, 1958; Reinecke \& Ansari, 2015; Verweij et al., 2006). The necessary preconditions underlying the applicability of conventional management simply do not exist in the context of wicked problems, not only at the level of individual organization, but perhaps even more importantly, at the level of public policy and regulations (Dorf \& Sabel, 1998; Sabel \& Zeitlin, 2012). But in that case, how can organizations help foster large-scale sustainability transformations?

\section{An Alternative Model}

Noting that conventional management approaches appear to be falling short when applied to the domain of sustainability, Ferraro, Etzion and Gehman (2015) recently theorized an alternative model for addressing grand challenges, based on the premise that "the fundamental principles underlying a grand challenge are the pursuit of bold ideas and the adoption of less conventional approaches to tackling large, unresolved problems” (Colquitt \& George, 2011: 432). In particular, they proposed that grand challenges such as climate change, water scarcity, poverty alleviation, and the safeguarding of human rights share three key analytical facets or dimensions. First, they are complex, involving a large array of systems, institutions and networks, and are thus given to multiple possible apprehensions by different actors. Second, they 
are fundamentally uncertain; their consequences cannot be broken down into a simple model of possible future states of the world with corresponding probabilities since it is impossible to imagine all possible states, let alone assess their probabilities. And third, they are evaluative, in that they cut across conventional epistemic, professional and ideological boundaries. Because of this, it is not easy to label them as solely social, economic or environmental issues, and different constituents may disagree about what the core problem actually is.

In theorizing how an unconventional management approach can yield systemic change on these issues, Ferraro, et al. (2015) proposed applying the sociological concept of robust action. Robust actions have been defined as "noncommittal actions that keep future lines of action open in strategic contexts where opponents are trying to narrow them" (Padgett \& Powell, 2012: 24). In particular, robust action is generative, in that it allows and even promotes a large set of further actions to be taken, thus remaining adaptive, particularly in the face of complexity and uncertainty.

In their analysis, Ferraro, et al. (2015) argued that three strategies are essential for successfully harnessing the power of robust action: participatory architecture, multivocal inscription and distributed experimentation (see Figure 1 for a visualization). Building on the concept of hybrid forums (Callon, Lascoumes, \& Barthe, 2009), participatory architectures are structures that enable not only initial engagement, but, more meaningfully, prolonged engagement, thereby enabling varied and diverse actors to interact. Sharing an affinity with boundary organizations (Guston, 2001; O’Mahony \& Bechky, 2008), in these forums different evaluative criteria can be introduced, authority is distributed, and accountability is lateral (Stark, 2009). Moreover, these architectures enable actors to meaningfully engage with counterparts, 
even when relations between them are publicly adversarial (Bartley, 2007; Furnari, 2014; Mair \& Hehenberger, 2014).

\section{-- Insert Figure 1 Here --}

While sustaining the engagement of participants is important, it is not necessarily sufficient to yield action. To promote action, guidelines, norms, routines and artifacts must be developed. Collectively, they can be understood as inscriptions (Latour, 1999). ${ }^{1}$ To make them useful and attractive to large numbers of actors, inscriptions must be multivocal; that is, they must be capable of sustaining different interpretations among various audiences. The key is to generate artifacts that can be interpreted flexibly (Pinch \& Bijker, 1987). For instance, the term sustainable development itself "means so many different things to so many different people and organizations" (Robinson, 2004: 373). But rather than a shortcoming, this attribute has sparked additional enrollment, providing "some common ground for discussion among a range of development and environmental actors who are frequently at odds" (Sneddon, Howarth, \& Norgaard, 2006: 254). In other words, multivocal inscriptions support discourse and coordination within and between multidisciplinary communities, without requiring explicit consensus (Bechky, 2003; Bowker \& Star, 1999). To the extent that these inscriptions allow for multiple plausible interpretations, they foster new forms of solutions, and support the participation of still more stakeholders (Beunza \& Stark, 2004; Kaplan, 2011).

A particular strength of multivocal inscriptions is their ability to engender diverse responses, thereby supporting the third robust strategy: distributed experimentation. Because sustainability is complex and multifaceted (i.e., a wicked problem), there are potentially multiple

\footnotetext{
${ }^{1}$ According to Latour (1999: 306) inscription "refers to all the types of transformations through which an entity becomes materialized into a sign, an archive, a document, a piece of paper, a trace."
} 
solutions and pathways that can be pursued. Accordingly, there is no way of knowing in advance how best to proceed, suggesting that top-down approaches have limited potential. Instead, distributed experimentation, initiated and implemented through participatory architectures, may generate a variety of effective responses. Successful experiments can be conceptualized as small wins that generate momentum:

Once a small win has been accomplished, forces are set in motion that favor another small win. When a solution is put in place, the next solvable problem often becomes more visible. This occurs because new allies bring new solutions with them and old opponents change their habits. Additional resources also flow toward winners, which means that slightly larger wins can be attempted. (Weick, 1984: 43)

These small wins can take many forms, ranging from personal satisfaction to organizational financial returns, and are determined in each context by the participants themselves, not necessarily in full accordance with each other. Their potency is in the affordances they provide participants to pursue successive, larger wins. Moreover, iteration, repetition, and continuous learning help actors maintain engagement and pursue additional experimentation (Dietz et al., 2003; Simon, 1996).

In sum, Ferraro, et al. (2015) argued that participatory architecture, multivocal inscription and distributed experimentation are potentially robust strategies for tackling major issues related to sustainability. Although they posited that this model may be effective in linking small scale actions to large scale outcomes by fostering novelty generation and sustained engagement, they did not offer evidence that it would be effective. In particular, their leadership model is susceptible to lethargy, dithering and ineffectiveness while systemic transformations to sustainability are monumental undertakings that are becoming increasingly urgent. Here, we seek to expand upon this model using empirical evidence from prior academic literature, and attempt to gauge its effectiveness. 


\section{Putting Robust Action to Work}

How likely is it for small wins to generate grand scale transformations? Prior studies suggest that robust action can in fact bring about tremendous changes. For instance, Hargadon and Douglas (2001) showed how Edison and his team applied the precepts of robust action by designing the light bulb and its accompanying electric system to superficially follow the templates of the dominant gas industry in order to appear familiar to the public. Instead of extolling the superiority of electric lighting, they hobbled it, content to displace gas lighting one building and one city block at a time.

This evidence suggests that Edison triumphed over the gas industry not by clearly distinguishing his new system from but, rather, by initially cloaking it in the mantle of these established institutions... At the same time, by structuring his system as he did, he also maintained its ability to evolve beyond that limited understanding and use. (Hargadon \& Douglas, 2001: 479-480)

In similar fashion, demonstrating how small wins can engender transformative change, Rao (2008) illustrated how distributed, grassroots actors have paved the way for radical innovations, ranging from mass market automobiles, to craft microbreweries, to nouvelle cuisine in France (see also Kay, 2012; Sims, 2011).

Clearly, robust action can work. But is there any evidence that such an approach could work in the case of sustainability challenges? In the sections that follow we take up this question by considering three exemplary case studies: wind power, sustainability reporting and microcredit (see Table 1 for an overview). Collectively, these three cases allow us to examine robust action across a range of sustainability challenges, including energy and the environment, corporate governance and accountability, and poverty alleviation and development. In other words, our three cases are revelatory settings (Patton, 2002; Pettigrew, 1990) for investigating the potentials and limitations of robust action. In each case study we consider the extent to which 
distributed experimentation, participatory architecture and multivocal inscription were involved, as well as the extent to which grand scale sustainability transformations have been achieved. -- Insert Table 1 Here --

\subsection{Wind Power}

Due to concerns about sustainability and climate change, energy is one of the most pressing challenges of the twenty-first century. Over the last 40 years, wind power has emerged as an option for dramatically reducing human dependence upon fossil fuels. As early adopters, Denmark and the United States provide an interesting contrast. In 2013, Denmark generated over $33 \%$ of total demand (or $11.1 \mathrm{TWh}$ ) from wind power, up from a mere 6\% in 1996 (Karnøe, 1999; Vittrup, 2014). The United States led the world in absolute production, generating 168 TWh (or 4\% of energy demand) from wind power (Energy Information Administration, 2014).

However, Denmark and the United States have followed very different paths. In comparing the historical evolution of wind power in these two countries Garud and Karnøe (2003) showed that Denmark pursued a low-tech "bricolage" strategy, whereas the United States pursued a high-tech "breakthrough" strategy. The authors concluded, "a bricolage approach that begins with a low-tech design but ramps up progressively is able to prevail over a high-tech breakthrough approach" (Garud \& Karnøe, 2003: 296). Drawing on prior research, we revisit Denmark's emergence as a wind "super-power."

\subsubsection{Participatory Architecture}

Starting in the 1970s, a wide variety of Danish actors became involved in wind power. For instance, owner-users initiated a series of "wind meetings" (Garud \& Karnøe, 2003; Karnøe, 1990). Held several times each year, these meetings provided a forum for sharing knowledge and 
expanding networks. Focused on enrolling stakeholders from six different domains, an association was established:

1) with politicians to create a regulatory framework; 2) with wind turbine producers to make design improvements; 3) with electrical utilities associations to establish payments and conditions for grid connection; 4) with insurance companies to cover component failures; 5) with consultants to seek assistance for individuals and cooperatives in making investments in wind turbines; and 6) with the government to provide national planning tools and regulations for local siting of wind power such as landscape classification. (Karnøe \& Garud, 2012: 739-740)

The association established a wind turbine test station that was used to certify wind turbine designs. Certification was required in order to benefit from a government subsidy worth $30 \%$ of the total cost of a wind turbine. Consequently, producers were forced to interact with the test station, which in turn "facilitated numerous iterations of designs, construction, tests and problem-solving prior to the approval of a new turbine" (Garud \& Karnøe, 2003: 290). Over time, those involved in the industry constituted a "specialized industrial network of users and suppliers" (Karnøe, 1990: 120).

By comparison, NREL, the test station's counterpart in the United States, was unable to develop extensive, on-going, trusting relationships with domestic wind turbine firms. Additionally, in the United States, wind turbine engineers were "insulated from the hands-on problems encountered in turbine construction and maintenance" leading to dampened and delayed feedback between users and producers (Garud \& Karnøe, 2003: 287-288). Engineers were discouraged (and in some cases prohibited) from talking with their peers for fear of disclosing trade secrets. Teams had little continuity from one generation of turbines to the next. Supplier relationships were one-time or short-term, motivated by profits rather than learning (Garud \& Karnøe, 2003). Compared with Denmark, there were no mechanisms for information 
disclosure. When American turbines later began failing in large numbers, the only feedback came in the form of lawsuits (Garud \& Karnøe, 2003).

\subsubsection{Multivocal Inscription}

Initially, many of those who became involved in the Danish wind turbine industry had prior experience with agriculture machinery. This led them to frame wind turbines as a series of practical problems. Because they lacked theoretical knowledge of turbine aerodynamics, they frequently solved problems by "throwing metal" at them, resulting in heavy-weight low-speed designs that "unintentionally reduced design risk by insuring that internal weight overshadowed aerodynamic loads" (Garud \& Karnøe, 2003: 285; see also Karnøe, 1990). Early customers, who were "owner-operators," also contributed to this bottom-up approach. Namely, in order to protect their investments in wind turbines, "early owner-users mobilized... to seek design features that would enhance the safety and reliability of wind turbines" (Garud \& Karnøe, 2003: 282). As a result, Denmark's wind power sector consolidated around an "unsophisticated," pliant design process that brought together multiple communities, including producers, users, regulators, and so forth, each of whom had different reasons for getting involved, and different ways of contributing to the unfolding work.

By comparison, designs that had proven acceptable in the Danish context were criticized by proponents of wind power in the United States as being "too simplistic" (Garud \& Karnøe, 2003: 283) and “old-fashioned" (Karnøe, 1999: 161). For instance, the well-known "Juul/Gedser" design that was repeatedly licensed and copied in Denmark was rejected in the United States. After all, "why spend government money on a wind turbine that already exists" (Karnøe, 1999: 162)? Instead, those in the United States approached the problem more narrowly and specifically "from an engineering science knowledge base, conceptualizing problems in 
terms of the formal, theoretical language of aerodynamics and structural dynamics" (Garud \& Karnøe, 2003: 286). Some in the United States advocated for a moderately sophisticated threebladed light-weight design (Garud \& Karnøe, 2003: 283), prompting the head of NREL to exclaim, "with time, the light-weight, cost-effective turbine will win the race" (Garud \& Karnøe, 2003: 291). But this engineering and theory driven mindset backfired in several notable ways. For instance, one reason that American designs worked in theory, but not in practice, was due to flawed assumptions about wind loads. Whereas aerospace-derived models assumed steady wind flows, in reality wind loads were variable (Garud \& Karnøe, 2003: 287).

\subsubsection{Distributed Experimentation}

Due to the participatory nature of the Danish wind sector, it employed people from diverse backgrounds: blacksmiths, fitters, carpenters, electricians, and even school teachers. Consequently, "instead of pursuing a design intensive R\&D approach, [Danish] firms deployed prototypes designed with simple engineering heuristics to engender a process of trial-and-error learning" (Garud \& Karnøe, 2003: 282). Cumulatively, "hundreds of experiments were carried out" (Karnøe, 1990: 113) and by the end of the 1980s, several hundred wind turbines had been installed. This initial momentum, and its portrayal in a variety of books, movies and academic articles, in turn fueled more debates and experiments (Karnøe \& Garud, 2012).

Additionally, because these installations were dispersed throughout Denmark and operated under different conditions, they created multiple learning opportunities. "Learning from multiple installation sites, in combination with learning on the shop floor, became the bases for design scale-ups" (Garud \& Karnøe, 2003: 295). But even as the industry was gaining momentum, for individual firms, the process could be ruthless. For instance, Riisager, developer 
of the first commercial wind turbine, saw its market share plummet from of $75 \%$ in 1979 , to $11 \%$ in 1980, and finally to just 1\% in 1982 (Karnøe, 1990).

In comparison, following the 1973 energy crisis, wind power also attracted considerable interest in the United States, resulting in more than \$486 million in federal funding for research and development between 1974 and 1992. However, the United States opted for a "linear topdown orientation and the quest for a breakthrough" (Garud \& Karnøe, 2003: 283; see also Karnøe, 1990). Perhaps surprisingly, compared with the Danish experience, in the United States these endeavors had "very limited exposure to real economic market criteria" (Karnøe, 1999: 156). Large engineering firms were the dominant actors and they favored the use of helicopter rotor blades as a design foundation, an approach that was eventually discovered to be inferior. Similarly, American producers rejected the dispersed market and focused instead on the "wind farm" concept that emerged in California, thereby limiting the amount of experimentation that was possible.

\subsubsection{Scaling Impact}

The development of wind power in both Denmark and the United States was triggered in the 1970s by a confluence of political, cultural and economic factors, including "increased environment concern, the OPEC embargo, the nuclear power debate, and some elements of 'small is beautiful' arguments about decentralization and zero-growth" (Karnøe, 1999: 153). The Danish wind turbine industry started small, and developed a series of "scale-ups" from 15-30 kW in 1974 , to $45-55 \mathrm{~kW}$ in 1980 , to $75-100 \mathrm{~kW}$ in 1985 , to $100-180 \mathrm{~kW}$ in 1987 , to $180-450 \mathrm{~kW}$ in 1989 (Karnøe \& Garud, 2012). Along the way, the wind turbine was transformed from a clunky, domestic source of power, into a sophisticated, utility-scale energy option. By the 1990s, the Danish wind turbine industry was ready to dominate in new markets such as Germany, the 
United Kingdom and Spain (Karnøe \& Garud, 2012). By comparison, the American approach required a leapfrog breakthrough that failed to materialize.

Despite their similar starting points, the two countries followed very different paths. By most measures, such as reduction of greenhouse gas emissions and economic impact, Denmark has attained greater success with wind power than the United States. Its competency in wind energy is a key component of Denmark's “Energy Strategy 2050," which targets a fully fossil fuel-free economy. Whereas the United States has remained relatively locked-in (Arthur, 1989; David, 1985) to a fossil fuel driven electricity system, Denmark has created its own path (Garud, Kumaraswamy, \& Karnøe, 2010), potentially shedding further light on where triggers for sustainability transformations may be located. Of course, as wind power technologies continue to develop, manufacturing scales up and installation expands, it remains to be seen whether Denmark will retain its leadership position. Yet, its employment of robust action played a key role in setting in motion the technological trajectory and global market acceptance of wind power as a viable source of energy.

\subsection{Sustainability Reporting}

For years, a diverse group of actors has endeavored to improve the transparency and accountability of multinational enterprises, especially with regard to sustainability-related environmental, social and governance issues. A variety of such efforts have come and gone, including the OECD's Guidelines for Multinational Enterprises (1976), the Sullivan Principles (1977), the ILO's Tripartite Declaration of Principles Concerning Multinational Enterprises (1977) and the Valdez Principles (1989). Against this backdrop, the Global Reporting Initiative (GRI) stands out as a success story. 
The GRI is a transnational governance body that sponsors a reporting standard that provides organizations a blueprint for measuring and reporting factors related to sustainability. The standard provides a set of reporting principles and specific indicators that organizations are encouraged to utilize in order to facilitate comparability. Currently, the GRI is the de facto standard for sustainability reporting, and is utilized by a majority of the world's largest corporations as well as many other for-profit, not-for-profit and governmental organizations.

\subsubsection{Participatory Architecture}

Since its introduction in the 1990s, the GRI has emphasized multi-stakeholder engagement. Its inclusivity has been described as "unlimited in size and composition" (Brown, de Jong, \& Levy, 2009: 573). Its two primary organizational sponsors were Ceres, an American nongovernmental organization comprised of environmental organizations, socially responsible investment professionals, institutional investors, and labor and religious organizations; and the United Nations Environment Program (Etzion \& Ferraro, 2010). As articulated by its co-founder and CEO, Allen White, a key priority for the GRI was to "find a place for each and every person who seeks to, or should, contribute" (Waddock \& White, 2007: 41). In practice, active participants include international consultancies such as AccountAbility and SustainAbility; major global accountancy firms; large multinational corporations and banks; international business associations such as the World Business Council for Sustainable Development, CSR Europe, Business for Social Responsibility, the Prince of Wales Business Leaders Forum, and the International Chamber of Commerce; and some civil society organizations, such as UKbased Forum for the Future (Brown, de Jong, \& Levy, 2009). Importantly, these participants became involved at different hierarchical levels in the organization, including various elected 
and non-elected technical, advisory, governance and oversight working groups, committees and councils.

\subsubsection{Multivocal Inscription}

The GRI purposely maintained ambiguous goals, thereby preserving an open roadmap for progress. The emphasis was on resolving specific, narrowly defined problems that needed to be overcome in order to develop a guideline for reporting on sustainability. According to Bob Massie, one of the GRI's co-founders:

You do not need to agree on the first principles. In fact, it is better to avoid having an explicit discussion of core values and the fundamental views on the social order. Instead, you focus on more instrumental ideas. This way people can agree on the actions at that level, they may even be willing to try to understand each other on the core level. (Brown, de Jong, \& Lessidrenska, 2009: 194)

One particular technique emphasized by the GRI was its recurrent use of analogy to create comparability between sustainability reporting and the more familiar concept of financial reporting (Etzion \& Ferraro, 2010). This analogy highlighted the principles that underlie financial reporting, such as relevance, timeliness and understandability. However, rather than constraining the nature of sustainability reporting, this inscription was multivocal and allowed users to pursue their own understanding of what these principles entail in the context of sustainability.

\subsubsection{Distributed Experimentation}

While the GRI provided guidelines for sustainability reporting, it did not stipulate templates, enforce conformity or become directly involved in auditing. This yielded significant heterogeneity in sustainability reports, as users learned about sustainability reporting by doing. Some of this experimentation was somewhat superficial, as exemplified by great diversity in report titles, page lengths and indicators used (Roca \& Searcy, 2012). Organizations have utilized stand-alone reports, annual reports, financial filings, websites and social media to 
disclose sustainability performance, including interactive dashboards and social media platforms, which allow users to create customized "report experiences" (Ceres, 2012).

More fundamentally, and as a direct result of multivocal inscription, users grappled with the substantive issues of what a sustainability report should encompass. For example, a key principle for the GRI and also for financial reporting is materiality — determining the salient aspects of performance that are most relevant for report readers. As users came to grips with this concept in the context of sustainability, they experimented with different models for determining and articulating the materiality of report content. This included user development of materiality matrices as decision-making tools for determining report content (Etzion \& Ferraro, 2010). In later years, as the advantages and disadvantages of materiality matrices became evident, further experimentation ensued. For example, SAP developed an approach to materiality more closely aligned with their overall business strategy (SAP, 2012). Other organizations, such as the International Integrated Reporting Council (IIRC), were founded to establish sustainability accounting standards leading to the development of additional definitions of materiality, which advocate a much tighter link between financial and sustainability materiality than previously espoused (Eccles \& Serafeim, 2013). ${ }^{2}$

\subsubsection{Scaling Impact}

By early 2014 , over 6,000 organizations had produced more than 14,000 sustainability reports using the GRI framework, and the fourth major revision of its framework, known as the G4 Sustainability Reporting Guidelines, had been published. At the same time, various actors were advocating for tighter integration of financial and sustainability reporting, recognizing that

\footnotetext{
${ }^{2}$ The IIRC was founded in 2010 as collaboration between the GRI, The Prince's Accounting for Sustainability Project (A4S), and the Sustainability Accounting Standards Board (SASB). It was then incorporated in July 2011, and accredited by the American National Standards Institute.
} 
a powerful lever for shifting corporate priorities remains the financial bottom line. In this domain, various far-reaching experiments are now occurring, including development of an environmental profit and loss statement that attempts to monetize the ecosystem services upon which a company and its entire value chain rely. Initially pioneered by Puma, the idea has been pursued by others, such as Novo Nordisk. Additionally, buoyed by the GRI's success, dozens of countries and stock exchanges have implemented mandatory sustainability disclosure guidelines, some of which explicitly reference the GRI guidelines (KPMG, 2013).

Intriguingly, Allen White and other central GRI figures, as well as other observers, have insisted that the GRI alone has not and cannot do enough to meaningfully alter corporate behavior and substantively increase planetary sustainability (Levy, Brown, \& de Jong, 2010; see also Behnam \& MacLean, 2011; Waddock \& White, 2007). In large part we agree with this assessment, but rather than perceiving it as a limitation or failure of the initiative, we perceive the GRI as having created avenues for expansion. Indeed, White and others have continued to push the organizational accountability agenda even further, through initiatives such as IIRC, SASB and the Global Initiative for Sustainability Ratings (GISR), and by pursuing institutional change that goes to the heart of the role of the corporation in society. In our view, these initiatives support fundamental transformations in the "rules of the game" (Hoffman \& Jennings, 2015; Jepperson, 1991), fueled by experience accumulated through the GRI project and the now taken-for-granted view (unheard of before the GRI attained initial acceptance) that not only does sustainability matter, but it can and should be tracked, analyzed and disclosed.

\subsection{Microcredit}

Poverty alleviation and economic development are longstanding challenges. For decades, developed countries have sought to ameliorate these conditions through top-down financial aid. 
However, more recently a new strategy has emerged in the form of microcredit. Microcredit is a form of financing based on the issuance of small, unsecured loans to individuals or groups in order to help borrowers start or expand business activities. Its raison d'etre is the provision of capital to the so-called unbanked: people who lack access to conventional financing opportunities. Popularized following the success of Grameen Bank, which was founded in 1983, microcredit diffused rapidly over the ensuing three decades, expanding from its initial focus on the extremely poor in Bangladesh to the poor throughout Asia, Latin America, Eastern Europe and sub-Saharan Africa. Roughly 200 million borrowers utilize microcredit services provided by hundreds of institutions each year (Reed, 2013).

\subsubsection{Participatory Architecture}

Microcredit services are offered by commercial banks, non-bank financial institutions, credit unions, rural bank initiatives and NGOs (Conning \& Morduch, 2011). These actors interact frequently, particularly through summits and conferences that facilitate diffusion of technology, practices and expertise. In addition to the lenders themselves, donors, academics and members of the nongovernmental development and aid communities attend such gatherings (Armendáriz \& Labie, 2011). Participatory architectures are particularly evident on the supply side of microcredit as vividly exemplified by Microvest I, a $\$ 60$ million fund founded in 2003, chaired by W. Bowman Cutter (a former managing director at venture capital firm Warburg Pincus) and financed by three non-profits: Mennonite Economic Development Associates, the humanitarian organization CARE, and a fund set up by the French Committee against Hunger and for Development (Conning \& Morduch, 2011).

Yet, this architecture is not as evident in the structures and operations of the microcredit providers themselves. Individual microcredit organizations generally target distinct populations, 
thereby reducing the extent of participation of diverse actors. Cull et al. (2009) found that commercial lenders typically have for-profit status, and focus on individual lending, larger loan sizes and fewer women customers, and that their balance sheets show lower costs per dollar lent, higher costs per borrower, and greater profitability (see also Zhao \& Wry, 2011). In contrast, nongovernmental microfinance organizations are more likely to employ group lending methods, allocate smaller loans, serve more women, rely more on subsidies, and show less profitability. This segmentation suggests that while the sector as a whole is diverse and promotes knowledge transfer, perhaps it is not truly participatory.

\subsubsection{Multivocal Inscription}

The concept of microcredit lends itself easily to multivocal inscription. In particular, it can be invoked by actors in the domains of aid and development as an effective means to alleviate poverty. Due to inherent comparisons with traditional banking, credit and finance, it also appeals to actors in the financial industry. And indeed, microcredit attracts lenders from both the for-profit and not-for-profit sectors: roughly 60 percent of lenders are not-for-profit organizations, although they control only some 30 percent of assets (Conning \& Morduch, 2011).

Resonating with the concept of hybridity (Callon et al., 2009), Battilana and Dorado (2010) argued that successful microcredit providers are hybrid organizations, blending two complementary logics — development and banking — into their value systems and identities. In doing so, they are able to effectively manage internal tensions around potential conflicts between banking and development. Hybridity also enables the employment of tools, practices and metrics from the for-profit banking sector, without losing sight of the overarching purpose of social betterment that microcredit organizations seek to promote (Zhao, 2012). 


\subsubsection{Distributed Experimentation}

Perhaps most striking in the evolution of microcredit is the experimentation that has taken place. Central among the experiments has been the target population. Microcredit originated with group lending practices that employed joint liability contracts in a "solidarity group" model (Armendáriz \& Morduch, 2010), but over time has expanded to include "village banks," which are similar yet larger groups that also employ internal lending practices, as well as individual lenders (Armendáriz \& Labie, 2011).

Even more experimentation has occurred on the supply side, where various mechanisms have been harnessed to increase the supply of capital. These include Internet based services such as Kiva.org, that allow individuals to lend small sums to specific entrepreneurs, and the now defunct MicroPlace, owned by eBay, which allowed individuals to use PayPal to bundle small investments with other individuals and fund microcredit organizations in the developing world (Khavul, 2010). Microcredit has also begun experimenting with more sophisticated financing mechanisms, such as securitization of loans and their subsequent sale as debt securities to institutions as varied as mutual funds, private equity firms and investment banks (Conning \& Morduch, 2011).

\subsubsection{Scaling Impact}

The impact of microcredit is a hotly debated topic, and the evidence so far is inconclusive. Perhaps unsurprisingly, many studies suggest that microcredit works for some (but not all) borrowers, depending both upon the performance indicators used, and various contingencies such as country, type of lending and size of loan (Karlan \& Goldberg, 2011). Others point to mission drift (Mersland \& Strøm, 2010) and problems of over-indebtedness which eventually ensnares some borrowers, even leading to suicide in some cases (Guérin, 
Morvant-Roux, \& Villarreal, 2013). An entire microcredit subsector imploded in the Indian state of Andhra Pradesh in 2011, and this failure was ascribed to misguided changes in regulatory policy (Maes \& Reed, 2012).

But, from a broader perspective, microcredit has generated several profound, positive effects. Based on its uptake and diffusion, microcredit spawned the larger field of microfinance, which now encompasses a range of services including credit, savings, insurance, mortgages, and retirement plans, all of which are denominated in small amounts, making them accessible to individuals previously shut out from formal means of borrowing and saving (Conning \& Murdoch, 2011; Khavul, 2010). Examining outcomes other than improved economic conditions, Sanyal (2009) found that group lending to women in India through microcredit had dramatic positive "unintended" consequences in terms of generating collective social action. In some cases, effects were observed in domains far removed from the realm of microfinance, in the form of mobilized responses to domestic violence against women, support of anti-liquor campaigns, and acquisition of public goods for local communities.

Perhaps most interesting in this regard is the case of microcredit in Bolivia, as thoroughly documented by Gonzalez-Vega and Villafani-Ibarnegaray (2011; see also Dorado, 2013). In Bolivia, microcredit emerged as a way to provide financing for the urban (as opposed to the rural) poor, and evolved through continuous innovation, adaptation and experimentation rather than through adoption of best practices from other geographies. The key player that led the initial microcredit revolution was BancoSol, the world's first private commercial bank specializing in microfinance. Very quickly, several competing institutions emerged, employing different lending models and target populations, allowing "experiments [to be] tested and contrasted" (GonzalezVega \& Villafani-Ibarnegaray, 2011: 207). This experimentation and diversity led to the 
realization that group-lending — a cornerstone of the conventional microcredit philosophy—is less suited to the Bolivian context than individual loans.

Moreover, even though BancoSol was a for-profit entity, others experimented with nonprofit forms. The success of some of these organizations led to the development of tailored regulatory guidance, which among other innovations, allowed non-profits to provide training, health and other non-financial services alongside financial offerings. By many parameters, including number of clients and regions served, loan repayment rates, liquidity risk and growth, the microcredit sector in Bolivia vastly outperforms the traditional banking sector. As such, through the provision of high-quality and low-cost services, the Bolivian microfinance sector has contributed not only to providing financial access and non-financial services to many Bolivians, but to strengthening the country's entire financial system.

\section{Discussion}

In this concluding section, we reconsider what the three case studies collectively reveal about the potential strengths and limitations of robust action for advancing sustainability. We

then briefly compare robust action with two other well-known sustainability approaches: common pool resource management (Dietz et al., 2003; Ostrom, 1990) and the framework for strategic sustainable development (Ny et al., 2006; Robèrt et al., 2002). Although our comparison is necessarily brief, it highlights some notable points of contact and points of difference, and suggests some areas for future research.

\subsection{Robust Action Strategies for Sustainability}

In this paper, we conceptualized sustainability as a grand challenge, a manifestation of a wicked problem characterized by complexity, uncertainty and evaluativity. We then introduced recent work that has proposed robust action strategies for dealing with such situations (Ferraro et 
al., 2015). In an effort to explore the usefulness of this approach, we developed detailed case studies of wind power, sustainability reporting and microcredit. In each case, we examined the role of distributed experimentation, multivocal inscription and participatory architecture. Given the theme of the special issue, we were especially sensitive to understanding how robust action strategies targeting small wins and low hanging fruit might generate large-scale, or field-level sustainability transformations.

Comparing these three disparate contexts, we see an accretive process (Dorado \& Ventresca, 2013; Garud \& Karnøe, 2001). Emergent concerns such as renewable energy, corporate accountability, and poverty alleviation gave rise to local, situated experiments. As would be expected, some experiments were more successful than others. Rather than centrally planned or imposed, these experiments were distributed across heterogeneous actors, such as producers, consumers, regulators, competitors, activists, enthusiasts, academics and others. This process frequently resulted in the formation of new organizations and forms, and these new actors subsequently became involved in shaping the path even as it was emerging. As different options circulated, some generated "momentum" (Hughes, 1993); that is, they began to become enmeshed with different groups, thereby generating interest among additional stakeholders and promoting expanded enrollment (Callon, 1986). Taken together, our case studies of wind power, sustainability reporting and microcredit suggest that utilization of the three robust action strategies enabled breakthrough, field-level sustainability transformations.

The three cases also highlight some key differences that may be worthy of further research. For instance, despite its widespread adoption, the Global Reporting Initiative suggests there are some limits to what robust action can achieve in terms of substantially altering the role of the corporation in society. Despite the GRI's success, multinational corporations have not 
been transformed wholesale. At the same time, the GRI appears to be serving as a platform for additional experimentation, setting in motion the possibility of additional wins. In particular, the GRI increasingly integrates sector-specific or measure-specific standards into its guidelines, such as the WRI and WBCSD's Greenhouse Gas Protocol, and the International Labor Organization's Conventions. Complementarily, other private transnational initiatives such as ISO 26000, AA1000, SA8000, and the UN Global Compact integrate the GRI into their guidelines. Cumulatively, the net effect is the creation of a dense, highly participatory network that promotes an ever-expanding toolkit for promoting corporate sustainability and enabling further experimentation.

The wind power case study is an impressive example of how a small wins strategy may yield faster results than alternative trajectories, such as the breakthrough strategy explicitly pursued in the United States. Indeed, despite its humble beginnings, wind power is now deeply embedded in Denmark, to the point where it has become part of the country's identity, setting up the possibility that the country could be completely "fossil fuel-free" by 2050. Perhaps most importantly, it provides a vivid counterexample to the "Apollo Moonshot" and "Manhattan Project" paradigms, which call for top-down, coordinated, war-scale mobilization to resolve grand challenges. This is not to say that hierarchy is flawed per se, but rather to highlight the value of distributed authority, lateral accountability and mutual monitoring (Stark, 2009). Similarly, the microcredit case shows how relatively laissez-faire policies—not top-down directives — enabled various alternatives to be deployed, some of them quite successfully. Reminiscent of Denmark's experience with wind power, there is emerging evidence that Bolivia's small win approach is leading to breakthrough transformations that not only impact those at the bottom of the pyramid, but an entire society. 
On the whole then, these three cases provide a variety of evidence in support of robust action. Nothing in these cases suggests that robust action cannot help resolve other seemingly intractable sustainability problems, such as creating rural telecommunications networks, ensuring a clean water supply, and providing quality healthcare. At the same time, robust action might not succeed in resolving all sustainability challenges, and of course a set of successful case studies cannot provide a definitive answer as regards generalizability. Several constraints may curtail the effectiveness of such an approach. A very real potential pitfall with robust action is the inclusion of skeptics or actors with plainly contradictory interests who may try to sabotage or undermine progress toward sustainability, as has happened in the case of climate change (Garud, Gehman, \& Karunakaran, 2014; Grundmann, 2012). To be effective, robust action must be applied in a manner that insures heterogeneous participation on the one hand, but does not succumb to fragmentation or cooptation on the other. One specific avenue for future research is to investigate the effective management of different participatory architectures, and to explore how these architectures evolve over time.

A second shortcoming of local action relates to the time it takes to harness social learning and translate it into action. The mechanisms we identified - participatory architecture, distributed experimentation, and multivocal inscriptions - take time to bear fruit, and action might stall or be pursued lethargically. Coordination of effort and knowledge, in the traditional sense, may prove to be difficult, given the many "false starts" and "dead ends" that are endemic to sustainability journeys (Garud \& Gehman, 2012). If so, change may not occur fast enough to respond to urgent sustainability challenges. This conundrum opens up a potentially larger research agenda around the paradox of "steering the unsteered," (Shove \& Walker, 2010) or providing enough structure to ensure progress, while concurrently encouraging divergent perspectives as a source 
of novelty generation. Finally, to the extent that robust action appears to be working at a local level, it is unclear whether such local solutions will coalesce into a global solution. Our case studies provide some evidence of how such scaling-up might occur, but ultimately this is an empirical question for further research.

\subsection{Comparison with Other Sustainability Approaches}

In this regard, it is beneficial to explore whether robust action can be applied in conjunction with other sustainability approaches such as common pool resource management (Dietz et al., 2003; Ostrom, 1990) and the framework for strategic sustainable development (Ny et al., 2006; Robèrt et al., 2002). Below we highlight some similarities and differences between robust action and these approaches for addressing sustainability challenges (see Table 2 for an overview). It is in examining the extent to which robust action and these other leadership approaches can be aligned that we believe the greatest potential for future research lies.

-- Insert Table 2 Here --

Research on common pool resource (CPR) management, or "governing the commons" (Ostrom, 1990) has in recent years expanded from its original contexts — such as small-scale fisheries and management of grazing lands — to large-scale sustainability concerns. Ostrom and colleagues have suggested that the mechanisms which encourage self-managed groups to work on a continuous trial-and-error basis and generate sophisticated, effective solutions are also applicable for larger systems (Dietz et al., 2003; Ostrom, 2009). Somewhat similar to the ideas

we have espoused above, CPR management can successfully engage with global challenges if these can be accurately construed as the sum of numerous local problems. Thus, Ostrom suggested aggregating wins on multiple local geographies as a possible solution for global issues, such as sustainable oceanic ecosystems (Ostrom, 1990: 27). 
Yet, where Ostrom and colleagues essentially direct their efforts towards improving public policy, robust action does not focus narrowly on re-shaping governance structures. Instead, the focus is on leveraging general operating mechanisms that are useful across various contexts and that engage multiple constituencies. Notwithstanding, CPR management can potentially inform robust action with regards to the prevention of cooptation, because the architecture it proposes allows for accountability to flow in all directions, not just top-down or bottom-up. It also can be effective in promoting urgency, by directly involving those whose livelihoods are at stake, and for whom meaningful action is imperative.

Another notable approach to sustainability is the Framework for Strategic Sustainable Development (FSSD) (Ny et al., 2006; Robèrt et al., 2002; 2005; 2013), which has been deployed effectively over the past decades in a variety of organizations and communities. The FSSD is founded upon a rigorous, science-based conceptualization of sustainability: the FSSD sustainability principles are derived from a planetary perspective and serve as boundary conditions within which possible solutions within sectors can be harmonized at a global scale. ${ }^{3}$ FSSD does not prescribe specific actions to address the planetary constraints it identifies, but it does grant science a position of epistemological primacy, sidestepping the fundamental challenge that the pursuit of sustainability entails: translating scientific consensus into political and social action. Recent research emphasizes that effective action is more likely to emerge by confronting and debating the different frames we use to understand sustainability than by insisting on adherence to one dominant frame (Garud and Gehman, 2012; Nisbet, 2009). Robust action builds explicitly on this evidence by employing multivocal inscription to sustain long term engagement and to create opportunities for novelty generation.

\footnotetext{
${ }^{3}$ We thank one of our reviewers for precisely clarifying the core tenets of FSSD.
} 
Yet, here too, there are important potential linkages that can inform future theorization. For example, FSSD's use of backcasting strategies to stimulate group creativity certainly resembles distributed experimentation, providing pathways for translating small wins into major advances. Moreover, the FSSD provides important architectural principles for engaging various constituencies in processes of visioning and innovation. Accordingly, an interesting topic for future research is whether or not robust action in combination with FSSD can strengthen the effectiveness of both approaches.

\section{Conclusion}

At first glance, the counterintuitive nature of robust action, its potentially unhurried pace, and its perceived lack of conviction and ideology may seem to pose a poor antidote to the sustainability crisis. Nevertheless, several decades of real-world experience with conventional management approaches reveals that traditional leadership has, by and large, not been effective in promoting sustainability. The case of climate change is paradigmatic. Despite an overwhelming scientific consensus, we have so far failed to act collectively to address the problem, not because we did not know what needed to be done, but because we employed conventional management frameworks (Jamieson, 2014). Precisely because our failure in combatting climate change and other sustainability issues is so apparent, it is imperative to thoroughly understand the shortcomings of current management models and, armed with that knowledge, change our approaches accordingly.

We believe that leadership through robust action may be particularly well suited to our times, not only because the sustainability crisis is so dire, but also because our organizational and social landscapes themselves are undergoing seismic shifts, rendering traditional models of

leadership less effective. At present, organizations are less central in our economies (Davis, 
2009,2013 ), giving rise to fluid networks of affiliation oriented to goal attainment, as opposed to the lumbering hierarchical monoliths that towered over the twentieth century landscape. Similarly, nation-states are weaker, no longer as dominant as they once were in shaping policy. (Habermas, 2001; Scherer \& Palazzo, 2011). A large number of national and transnational issues are thus increasingly resolved through private regulatory processes and multi-stakeholder initiatives (Bartley, 2007; Mena \& Palazzo, 2012), rather than through the traditional nation-state tools of fiat and redistribution. Technology, with the Internet of course as its defining feature, promotes unlimited accessibility to knowledge and ideas, thereby spurring decentralized innovation. Younger generations are bringing energy, commitment, and collaborative problem solving skills to problems that they increasingly understand are central to their futures. But the combined forces of local, distributed and engaged actors, combined with the enabling power of technology, will not translate into effective solutions, unless we devise a template that explains how emerging local solutions can scale to address the global challenges we face (Morozov, 2013). In this reality of changing societal and organizational conditions, it is important to apply a framework that unflinchingly departs from accepted leadership dogma, and that is in fact tailored to this era in human history. Robust action fits the bill. 


\section{Acknowledgements}

We thank Eric Zhao for his helpful advice and comments on the microcredit case study. The third author gratefully acknowledges funding from the European Research Council under the European Union's Seventh Framework Programme - ERC-2010-StG 263604-SRITECH. 


\section{REFERENCES}

Allison, G. T. 1972. Essence of Decision: Explaining the Cuban Missile Crisis. Little Brown \& Co.

Andrews, K. R. 1971. The Concept of Corporate Strategy. Homewood: Dow Jones.

Ansoff, H. I. 1965. Corporate strategy. New York: McGraw-Hill.

Armendáriz, B., \& Labie, M. 2011. Introduction and Overview: An Inquiry into the Mismatch in Microfinance. In B. Armendáriz \& M. Labie (Eds.), The Handbook of Microfinance: 313. Hackensack, NJ: World Scientific.

Armendáriz, B., \& Morduch, J. 2010. The Economics of Microfinance. Cambridge: MIT Press.

Arthur, W. B. 1989. Competing Technologies, Increasing Returns, and Lock-in by Historical Events. Economic Journal, 99: 116-131.

Bartley, T. 2007. Institutional Emergence in an Era of Globalization: The Rise of Transnational Private Regulation of Labor and Environmental Conditions. American Journal of Sociology, 113: 297-351.

Battilana, J., \& Dorado, S. 2010. Building Sustainable Hybrid Organizations: The Case of Commercial Microfinance Organizations. Academy of Management Journal, 53: 14191440 .

Bechky, B. A. 2003. Object Lessons: Workplace Artifacts as Representations of Occupational Jurisdiction. American Journal of Sociology, 109: 720-752.

Behnam, M., \& MacLean, T. L. 2011. Where Is the Accountability in International Accountability Standards? A Decoupling Perspective. Business Ethics Quarterly, 21: $45-72$.

Beunza, D., \& Stark, D. 2004. Tools of the Trade: The Socio-Technology of Arbitrage in a Wall Street Trading Room. Industrial and Corporate Change, 13: 369-400.

Bowker, G. C., \& Star, S. L. 1999. Sorting Things Out: Classification and Its Consequences. Cambridge: MIT Press.

Brown, H. S., de Jong, M., \& Lessidrenska, T. 2009. The Rise of the Global Reporting Initiative: A Case of Institutional Entrepreneurship. Environmental Politics, 18: 182-200.

Brown, H. S., de Jong, M., \& Levy, D. L. 2009. Building institutions based on information disclosure: Lessons from GRI's sustainability reporting. Journal of Cleaner Production, 17: 571-580.

Cabantous, L., \& Gond, J.-P. 2011. Rational Decision Making as Performative Praxis:

Explaining Rationality's Éternel Retour. Organization Science, 22(3): 573-586. 
Callon, M. 1986. Some Elements of a Sociology of Translation: Domestication of the Scallops and the Fishermen of St. Brieuc Bay. In J. Law (Ed.), Power, Action and Belief: 196233. Boston: Routledge \& Kegan Paul.

Callon, M., Lascoumes, P., \& Barthe, Y. 2009. Acting in an Uncertain World: An Essay on Technical Democracy. Cambridge: MIT Press.

Cash, D. W., Adger, W. N., Berkes, F., Garden, P., Lebel, L., et al. 2006. Scale and Cross-Scale Dynamics: Governance and Information in a Multilevel World. Ecology and Society, 11(2): 8 .

Ceres. 2012. The Road to 2020: Corporate Progress on The Ceres Roadmap for Sustainability. https://www.ceres.org/roadmap-assessment/downloads/downloads.

Chandler, A. D. 1962. Strategy and Structure: Concepts in the history of American industrial enterprise. Cambridge: MIT Press.

Cohen, M. D., March, J. G., \& Olsen, J. P. 1972. A Garbage Can Model of Organizational Choice. Administrative Science Quarterly, 17: 1-25.

Colquitt, J. A., \& George, G. 2011. Publishing in AMJ-Part 1: Topic Choice. Academy of Management Journal, 54: 432-435.

Conning, J., \& Morduch, J. 2011. Microfinance and Social Investment. Annual Review of Financial Economics, 3(1): 407-434.

Cull, R., Demirgüç-Kunt, A., \& Morduch, J. 2009. Microfinance Meets the Market. Journal of Economic Perspectives, 23(1): 167-192.

David, P. A. 1985. Clio and the Economics of Qwerty. American Economic Review, 75: 332337.

Davis, G. F. 2009. Managed by the Markets: How Finance Reshaped America. New York: Oxford University Press.

Davis, G. F. 2013. After the Corporation. Politics \& Society, 41: 283-308.

Dietz, T., Ostrom, E., \& Stern, P. C. 2003. The Struggle to Govern the Commons. Science, 302: 1907-1912.

Dobbin, F., \& Jung, J. 2010. The Misapplication of Mr. Michael Jensen: How Agency Theory Brought Down the Economy and Why it Might Again. Research in the Sociology of Organizations, 30: 29-64.

Dorado, S. 2013. Small Groups as Context for Institutional Entrepreneurship: An Exploration of the Emergence of Commercial Microfinance in Bolivia. Organization Studies, 34: 533 557. 
Dorado, S., \& Ventresca, M. J. 2013. Crescive Entrepreneurship in Complex Social Problems: Institutional Conditions for Entrepreneurial Engagement. Journal of Business Venturing, 28: 69-82.

Dorf, M. C., \& Sabel, C. F. 1998. A Constitution of Democratic Experimentalism. Columbia Law Review, 98: 267-473.

Eccles, R. G., \& Serafeim, G. 2013. The Performance Frontier. Harvard Business Review, 91(5): 50-60.

Energy Information Administration. 2014, March. Electric Power Monthly with Data for January 2014. U.S. Department of Energy, http://www.eia.gov/electricity/monthly/pdf/epm.pdf.

Etzion, D., \& Ferraro, F. 2010. The Role of Analogy in the Institutionalization of Sustainability Reporting. Organization Science, 21: 1092-1107.

Ferraro, F., Etzion, D., \& Gehman, J. 2015. Tackling Grand Challenges Pragmatically: Robust Action Revisited. Organization Studies, 36(3): 363-390.

Furnari, S. 2014. Interstitial Spaces: Micro-Interaction Settings and the Genesis of New Practices between Institutional Fields. Academy of Management Review, Forthcoming.

Garud, R., \& Gehman, J. 2012. Metatheoretical Perspectives on Sustainability Journeys: Evolutionary, Relational and Durational. Research Policy, 41: 980-995.

Garud, R., Gehman, J., \& Karunakaran, A. 2014. Boundaries, Breaches, and Bridges: The Case of Climategate. Research Policy, 43: 60-73.

Garud, R., Jain, S., \& Tuertscher, P. 2008. Incomplete by Design and Designing for Incompleteness. Organization Studies, 29: 351-371.

Garud, R., \& Karnøe, P. 2001. Path Creation as a Process of Mindful Deviation. In R. Garud \& P. Karnøe (Eds.), Path Dependence and Creation: 1-38. Mahwah: Erlbaum.

Garud, R., \& Karnøe, P. 2003. Bricolage Versus Breakthrough: Distributed and Embedded Agency in Technology Entrepreneurship. Research Policy, 32: 277-300.

Garud, R., Kumaraswamy, A., \& Karnøe, P. 2010. Path Dependence or Path Creation? Journal of Management Studies, 47: 760-774.

Garud, R., Tuertscher, P., \& Van de Ven, A. H. 2013. Perspectives on Innovation Processes. Academy of Management Annals, 7: 775-819.

George, G. 2014. Rethinking Management Scholarship. Academy of Management Journal, 57: $1-6$. 
Gonzalez-Vega, C., \& Villafani-Ibarnegaray, M. 2011. Microfinance in Bolivia: Foundations of the Growth, Outreach and Stability of the Financial System. In B. Armendáriz \& M. Labie (Eds.), The Handbook of Microfinance: 203-250. Hackensack, NJ: World Scientific.

Grundmann, R. 2012. The legacy of climategate: Revitalizing or Undermining Climate Science and Policy? Wiley Interdisciplinary Reviews: Climate Change, 3: 281-288.

Guérin, I., Morvant-Roux, S., \& Villarreal, M. 2013. Microfinance, Debt and OverIndebtedness: Juggling with Money. New York: Routledge.

Guston, D. H. 2001. Boundary Organizations in Environmental Policy and Science: An Introduction. Science, Technology, \& Human Values, 26: 399-408.

Habermas, J. 2001. The Postnational Constellation: Political Essays. (M. Pensky, Ed.). Cambridge, MA: MIT Press.

Hargadon, A. B., \& Douglas, Y. 2001. When Innovations Meet Institutions: Edison and the Design of the Electric Light. Administrative Science Quarterly, 46: 476-501.

Hawken, P. 2007. Blessed Unrest: How the Largest Movement in the World Came Into Being, and Why No One Saw It Coming. New York: Viking Penguin.

Hoffman, A. J., \& Jennings, P. D. 2015. Institutional Theory and the Natural Environment Research in (and on) the Anthropocene. Organization \& Environment, 28: 8-31.

Hughes, T. P. 1993. Networks of Power: Electrification in Western Society, 1880-1930. Baltimore: Johns Hopkins University Press.

Jamieson, D. 2014. Reason in a Dark Time: Why the Struggle Against Climate Change Failed -- and What It Means for Our Future. New York: Oxford University Press.

Jepperson, R. L. 1991. Institutions, Institutional Effects, and Institutionalism. In W. W. Powell \& P. J. DiMaggio (Eds.), The New Institutionalism in Organizational Analysis: 143-163. Chicago: University of Chicago Press.

Kaplan, R. S., \& Norton, D. P. 2008. Mastering the Management System. Harvard Business Review, 86(1): 63-77.

Kaplan, S. 2011. Strategy and Powerpoint: An Inquiry into the Epistemic Culture and Machinery of Strategy Making. Organization Science, 22: 320-346.

Karlan, D., \& Goldberg, N. 2011. Microfinance Evaluation Strategies: Notes on Methodology and Findings. In B. Armendáriz \& M. Labie (Eds.), The Handbook of Microfinance: 1758. Hackensack, NJ: World Scientific. 
Karnøe, P. 1990. Technological Innovation and Industrial Organization in the Danish Wind Industry. Entrepreneurship \& Regional Development: An International Journal, 2: $105-124$.

Karnøe, P. 1999. When Low-tech Becomes High-tech: The Social Construction of Technological Learning Processes in the Danish and the American Wind Turbine Industry. In P. Karnøe \& P. H. Kristensen (Eds.), Mobilizing Resources and Generating Competencies: The Remarkable Success of Small and Medium-sized Enterprises in the Danish Business System: 139-184. København: Handelshøjskolens Forlag.

Karnøe, P., \& Garud, R. 2012. Path Creation: Co-creation of Heterogeneous Resources in the Emergence of the Danish Wind Turbine Cluster. European Planning Studies, 20(5): 733-752.

Kay, J. 2004, January 17. Obliquity. Financial Times.

Kay, J. 2012. Obliquity: Why Our Goals Are Best Achieved Indirectly (Reprint edition). New York: Penguin Books.

Khavul, S. 2010. Microfinance: Creating Opportunities for the Poor? Academy of Management Perspectives, 24(3): 58-72.

KPMG. 2013. Carrots and Sticks. https://www.globalreporting.org/resourcelibrary/Carrots-AndSticks-Promoting-Transparency-And-Sustainbability.pdf.

Latour, B. 1999. Pandora’s Hope. Cambridge: Harvard University Press.

Leifer, E. M. 1991. Actors as Observers: A Theory of Skill in Social Relationships. New York: Garland.

Levy, D. L., Brown, H. S., \& de Jong, M. 2010. The Contested Politics of Corporate Governance: The Case of the Global Reporting Initiative. Business \& Society, 49: 88115.

Lindblom, C. E. 1958. Policy Analysis. American Economic Review, 48: 298-312.

Maes, J. P., \& Reed, L. 2012. State of the Microcredit Summit Campaign Report 2012. Microcredit Summit Campaign, http://www.microcreditsummit.org/uploads/resource/document/web_socr2012_english_62819.pdf.

Mair, J., \& Hehenberger, L. 2014. Front-Stage and Backstage Convening: The Transition from Opposition to Mutualistic Coexistence in Organizational Philanthropy. Academy of Management Journal, 57: 1174-1200.

March, J. G. 1991. Exploration and Exploitation in Organizational Learning. Organization Science, 2: 71-87. 
March, J. G. 2011. A Scholar's Quest. Journal of Management Inquiry, 20: 355-357.

Margolis, J. D., \& Walsh, J. P. 2003. Misery Loves Companies: Rethinking Social Initiatives by Business. Administrative Science Quarterly, 48: 268-305.

Markard, J., Raven, R., \& Truffer, B. 2012. Sustainability Transitions: An Emerging Field of Research and its Prospects. Research Policy, 41(6): 955-967.

Meadows, D. 2008. Thinking in Systems: A Primer. Chelsea Green Publishing.

Mena, S., \& Palazzo, G. 2012. Input and Output Legitimacy of Multi-Stakeholder Initiatives. Business Ethics Quarterly, 22: 527-556.

Mersland, R., \& Strøm, R. Ø. 2010. Microfinance Mission Drift? World Development, 38: 2836.

Miller, T. L., Grimes, M. G., McMullen, J. S., \& Vogus, T. J. 2012. Venturing for Others with Heart and Head: How Compassion Encourages Social Entrepreneurship. Academy of Management Review, 37: 616-640.

Mintzberg, H. 1973. The Nature of Managerial Work. Prentice-Hall.

Mintzberg, H. 1987. Crafting Strategy. Harvard Business Review, 65(5): 66-75.

Mintzberg, H. 2004. Managers, Not MBAs: A Hard Look at the Soft Practice of Managing and Management Development. San Francisco: Berrett-Koehler Publishers.

Morozov, E. 2013. To Save Everything, Click Here: Technology, Solutionism, and the Urge to Fix Problems that Don't Exist. Perseus.

Nisbet, M. C. 2009. Communicating Climate Change: Why Frames Matter for Public Engagement. Environment: Science and Policy for Sustainable Development, 51(2), $12-$ 23.

Ny, H., MacDonald, J. P., Broman, G., Yamamoto, R., \& Robért, K.-H. 2006. Sustainability Constraints as System Boundaries: An Approach to Making Life-Cycle Management Strategic. Journal of Industrial Ecology, 10(1-2): 61-77.

O’Mahony, S., \& Bechky, B. A. 2008. Boundary Organizations: Enabling Collaboration among Unexpected Allies. Administrative Science Quarterly, 53(3): 422-459.

Ostrom, E. 1990. Governing the Commons: The Evolution of Institutions for Collective Action. New York: Cambridge University Press.

Ostrom, E. 2009. A General Framework for Analyzing Sustainability of Social-Ecological Systems. Science, 325(5939): 419-422.

Padgett, J. F., \& Ansell, C. K. 1993. Robust Action and the Rise of the Medici, 1400-1434. American Journal of Sociology, 98: 1259-1319. 
Padgett, J. F., \& Powell, W. W. 2012. The Problem of Emergence. In J. F. Padgett \& W. W. Powell (Eds.), The Emergence of Organizations and Markets: 1-29. Princeton University Press.

Patton, M. Q. 2002. Qualitative research and evaluation methods, vol. 3rd. Thousand Oaks: Sage.

Pettigrew, A. M. 1990. Longitudinal Field Research on Change: Theory and Practice. Organization Science, 1: 267-92.

Pinch, T. J., \& Bijker, W. E. 1987. The Social Construction of Facts and Artifacts: Or How the Sociology of Science and the Sociology of Technology Might Benefit Each Other. In W. E. Bijker, T. P. Hughes, \& T. J. Pinch (Eds.), Social Construction of Technological Systems: 17-50. Cambridge: MIT Press.

Powell, W. W., Koput, K. W., \& Smith-Doerr, L. 1996. Interorganizational Collaboration and the Locus of Innovation: Networks of Learning in Biotechnology. Administrative Science Quarterly, 41: 116.

Prahalad, C. K. 2005. The Fortune at the Bottom of the Pyramid. Upper Saddle River, NJ: Wharton School Publishing.

Rao, H. 2008. Market Rebels: How Activists Make or Break Radical Innovations. Princeton: Princeton University Press.

Reed, L. 2013. State of the Microcredit Summit Campaign Report 2013. Microcredit Summit Campaign, http://stateofthecampaign.org/the-report/.

Reich, R. B. 2008. Supercapitalism: The Transformation of Business, Democracy, and Everyday Life. Vintage Books.

Reinecke, J., \& Ansari, S. 2015. Taming Wicked Problems: The Role of Framing in the Construction of Corporate Social Responsibility. Journal of Management Studies, Forthcoming. DOI: 10.1111/joms.12137.

Rittel, H. W. J., \& Webber, M. M. 1973. Dilemmas in a General Theory of Planning. Policy Sciences, 4: 155-169.

Robèrt, K.-H., Basile, G., Broman, G., Byggeth, S., Cook, D., et al. 2005. Strategic Leadership Towards Sustainability (2nd ed.). Karlskrona, Sweden: Blekinge Institute of Technology.

Robèrt, K.-H., Broman, G. I., \& Basile, G. 2013. Analyzing the Concept of Planetary Boundaries from a Strategic Sustainability Perspective: How Does Humanity Avoid Tipping the Planet? Ecology \& Society, 18(2): 80-88.

Robèrt, K.-H., Schmidt-Bleek, B., Aloisi de Larderel, J., Basile, G., Jansen, J. L., et al. 2002. Strategic Sustainable Development - Selection, Design and Synergies of Applied Tools. Journal of Cleaner Production, 10(3): 197-214. 
Robinson, J. 2004. Squaring the Circle? Some Thoughts on the Idea of Sustainable

Development. Ecological Economics, 48: 369-384.

Roca, L. C., \& Searcy, C. 2012. An Analysis of Indicators Disclosed in Corporate Sustainability Reports. Journal of Cleaner Production, 20(1): 103-118.

Sabel, C. F., \& Zeitlin, J. 2012. Experimentalist Governance. In D. Levi-Faur (Ed.), The Oxford Handbook of Governance: 169-183. New York: Oxford University Press.

Sanyal, P. 2009. From Credit to Collective Action: The Role of Microfinance in Promoting Women's Social Capital and Normative Influence. American Sociological Review, 74(4): 529-550.

SAP. 2012. Integrated Report. http://www.sapintegratedreport.com/2012/en/.

Scherer, A. G., \& Palazzo, G. 2011. The New Political Role of Business in a Globalized World: A Review of a New Perspective on CSR and its Implications for the Firm, Governance, and Democracy. Journal of Management Studies, 48: 899-931.

Shove, E., \& Walker, G. (2010). Governing Transitions in the Sustainability of Everyday Life. Research policy, 39(4), 471-476.

Simon, H. A. 1947. Administrative behavior. New York: Macmillan.

Simon, H. A. 1996. The Sciences of the Artificial (3rd ed.). MIT Press.

Sims, P. 2011. Little Bets: How Breakthrough Ideas Emerge from Small Discoveries. New York: Free Press.

Slawinski, N., \& Bansal, P. 2015. Short on Time: Intertemporal Tensions in Business Sustainability. Organization Science, Forthcoming. http://pubsonline.informs.org.login.ezproxy.library.ualberta.ca/doi/abs/10.1287/orsc.2014 .0960 .

Sneddon, C., Howarth, R. B., \& Norgaard, R. B. 2006. Sustainable Development in a PostBrundtland World. Ecological Economics, 57: 253-268.

Stark, D. 2009. The Sense of Dissonance. Princeton: Princeton University Press.

Verweij, M., Douglas, M., Ellis, R., Engel, C., Hendriks, F., et al. 2006. Clumsy Solutions for a Complex World: The Case of Climate Change. Public Administration, 84: 817-843.

Vittrup, C. 2014, January 15. 2013 was a record-setting year for Danish wind power. Energinet, http://energinet.dk/EN/El/Nyheder/Sider/2013-var-et-rekordaar-for-dansk-vindkraft.aspx.

Waddock, S., \& White, A. 2007. Interview: On Ceres, the GRI and Corporation 2020. Journal of Corporate Citizenship, 2007(26): 38-42. 
Weick, K. E. 1984. Small Wins: Redefining the Scale of Social Problems. American Psychologist, 39: 40-49.

World Commission on Environment and Development. 1987. Our common future. New York: Oxford University Press.

Yunus, M. 1999. Banker to the Poor: Micro-Lending and the Battle Against World Poverty. New York: PublicAffairs.

Zhao, E. Y. 2012. The Sustainability of Social Ventures: The Financial-Social Performance Debate in Microfinance. Academy of Management Proceedings, 2012: 1.

Zhao, E. Y., \& Wry, T. E. 2011. Societal Patriarchal Logics and the Emergence of Microfinance Organizations. Academy of Management Proceedings, 2011: 1-6. 
FIGURE 1: THEORETICAL MODEL OF ROBUST ACTION STRATEGIES

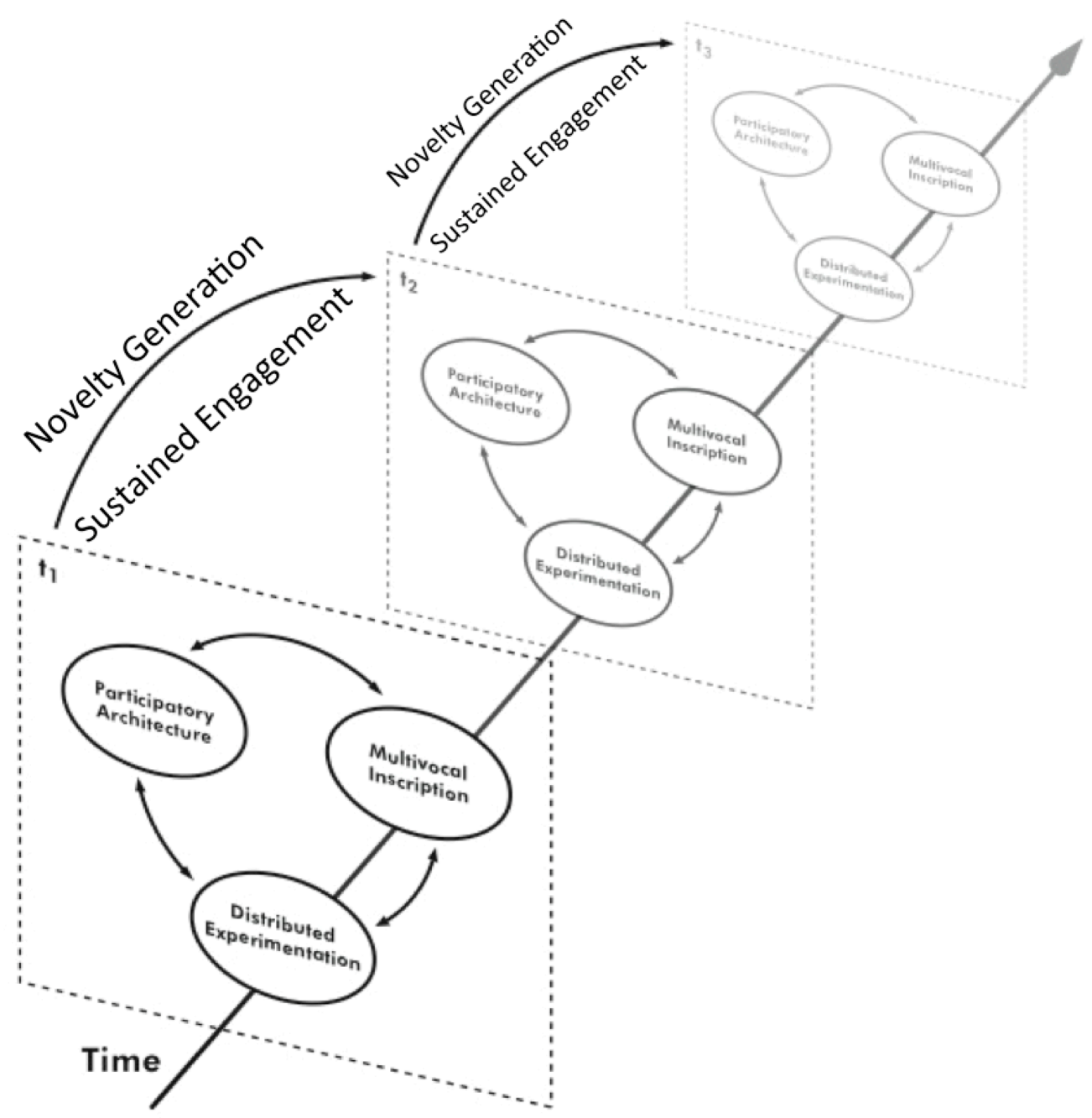

Source: Adapted from Ferraro, Etzion and Gehman (2015) 
TABLE 1: SUMMARY OF SUSTAINABILITY TRANSFORMATIONS THROUGH ROBUST STRATEGIES

\begin{tabular}{|c|c|c|c|c|c|}
\hline \multirow[t]{2}{*}{ Case } & \multirow{2}{*}{$\begin{array}{l}\text { Grand } \\
\text { challenge }\end{array}$} & \multicolumn{3}{|c|}{ Robust strategies } & \multirow[t]{2}{*}{ Scaling impact } \\
\hline & & $\begin{array}{l}\text { Participatory } \\
\text { architecture }\end{array}$ & $\begin{array}{l}\text { Multivocal } \\
\text { inscription }\end{array}$ & $\begin{array}{l}\text { Distributed } \\
\text { experimentation }\end{array}$ & \\
\hline Wind power & Energy & $\begin{array}{l}\text { Association of } \\
\text { users } \\
\text { Enrolling } \\
\text { stakeholders } \\
\text { from across } \\
\text { diverse domains }\end{array}$ & $\begin{array}{l}\text { Interdisciplinary } \\
\text { design } \\
\text { An eclectic mix of } \\
\text { professional and } \\
\text { practical } \\
\text { approaches }\end{array}$ & $\begin{array}{l}\text { Technological } \\
\text { prototypes } \\
\text { Installing wind } \\
\text { turbines based on a } \\
\text { trial-and-error } \\
\text { approach }\end{array}$ & $\begin{array}{l}\text { Emergence of wind } \\
\text { power trajectory } \\
\text { Feasibility of } \\
\text { renewable energy on } \\
\text { electric grid scale }\end{array}$ \\
\hline $\begin{array}{l}\text { Sustainability } \\
\text { reporting }\end{array}$ & $\begin{array}{l}\text { Organizational } \\
\text { accountability }\end{array}$ & $\begin{array}{l}\text { Governance rules } \\
\text { Integrating all } \\
\text { relevant and } \\
\text { interested actors }\end{array}$ & $\begin{array}{l}\text { Financial reporting } \\
\text { analogy } \\
\text { Maintaining diffuse } \\
\text { and ambiguous } \\
\text { goals through use of } \\
\text { analogy }\end{array}$ & $\begin{array}{l}\text { Heterogeneous } \\
\text { reporting practices } \\
\text { Providing general } \\
\text { guidelines that } \\
\text { allow organizations } \\
\text { to be selectively } \\
\text { transparent }\end{array}$ & $\begin{array}{l}\text { Institutionalization of } \\
\text { sustainability } \\
\text { reporting } \\
\text { Linkage between } \\
\text { organizational } \\
\text { strategy and } \\
\text { sustainability } \\
\text { virtually undisputed }\end{array}$ \\
\hline Microcredit & Poverty & $\begin{array}{l}\text { Transparent } \\
\text { competition } \\
\text { Strategies and } \\
\text { approaches of } \\
\text { providers are } \\
\text { easily observable } \\
\text { and widely } \\
\text { shared }\end{array}$ & $\begin{array}{l}\text { Hybrid logics } \\
\text { Blending } \\
\text { development and } \\
\text { banking logics }\end{array}$ & $\begin{array}{l}\text { Business model } \\
\text { heterogeneity } \\
\text { Implementing } \\
\text { multiple models of } \\
\text { supply and demand }\end{array}$ & $\begin{array}{l}\text { Inclusive finance } \\
\text { Can strengthen an } \\
\text { entire national } \\
\text { financial system }\end{array}$ \\
\hline
\end{tabular}


TABLE 2: A COMPARISON OF LEADERSHIP APPROACHES FOR ADVANCING SUSTAINABILITY

\begin{tabular}{|c|c|c|c|c|}
\hline & $\begin{array}{l}\text { Conventional } \\
\text { Management }\end{array}$ & $\begin{array}{l}\text { Common Pool Resource } \\
\text { Management }\end{array}$ & $\begin{array}{l}\text { Framework for } \\
\text { Strategic Sustainable } \\
\text { Development }\end{array}$ & Robust Action \\
\hline Typical contexts & $\begin{array}{l}\text { Hierarchical } \\
\text { organizations }\end{array}$ & $\begin{array}{l}\text { Commons (i.e., non- } \\
\text { excludable, rivalrous } \\
\text { goods) }\end{array}$ & $\begin{array}{l}\text { Sustainability, at } \\
\text { organizational and supra- } \\
\text { organizational levels }\end{array}$ & $\begin{array}{l}\text { Grand challenges (e.g. } \\
\text { climate change, } \\
\text { poverty) }\end{array}$ \\
\hline Participants & $\begin{array}{l}\text { Managers of an } \\
\text { individual organization }\end{array}$ & $\begin{array}{l}\text { Resource users and } \\
\text { regulators at overlapping } \\
\text { levels of jurisdiction }\end{array}$ & $\begin{array}{l}\text { Organization or } \\
\text { community members }\end{array}$ & $\begin{array}{l}\text { Multiple and changing } \\
\text { constituencies }\end{array}$ \\
\hline Ultimate goals & $\begin{array}{l}\text { Accomplishing } \\
\text { organizational mission; } \\
\text { survival }\end{array}$ & $\begin{array}{l}\text { Maintaining viable } \\
\text { common pool resources }\end{array}$ & $\begin{array}{l}\text { Predetermined through } \\
\text { system conditions }\end{array}$ & Emergent \\
\hline Theory of action & Instrumental action & $\begin{array}{l}\text { Institutional (rules and } \\
\text { norms) }\end{array}$ & $\begin{array}{l}\text { Game theoretic } \\
\text { backward-induction }\end{array}$ & $\begin{array}{l}\text { Novelty generation, } \\
\text { sustained engagement }\end{array}$ \\
\hline Model of authority & $\begin{array}{l}\text { Hierarchical control (top- } \\
\text { down) }\end{array}$ & $\begin{array}{l}\text { Adaptive governance } \\
\text { (both top down and } \\
\text { bottom up) }\end{array}$ & $\begin{array}{l}\text { Top down definition of } \\
\text { success, participatory } \\
\text { backcasting }\end{array}$ & $\begin{array}{l}\text { Weak formal authority, } \\
\text { or none at all }\end{array}$ \\
\hline Examples of success & $\begin{array}{l}\text { General Electric, Shell, } \\
\text { DuPont, and others }\end{array}$ & $\begin{array}{l}\text { Fisheries, oil fields, } \\
\text { grazing lands }\end{array}$ & $\begin{array}{l}\text { Electrolux, Whistler, and } \\
\text { others }\end{array}$ & $\begin{array}{l}\text { Wind power, GRI, } \\
\text { microcredit, and others }\end{array}$ \\
\hline Exemplary citations & $\begin{array}{l}\text { Andrews, 1971; Ansoff, } \\
\text { 1965; Chandler, 1962; } \\
\text { Simon, } 1947\end{array}$ & $\begin{array}{l}\text { Dietz et al., 2003; } \\
\text { Ostrom, 1990, } 2009\end{array}$ & $\begin{array}{l}\text { Ny et al., 2006; Robèrt et } \\
\text { al., 2002; 2005; } 2013\end{array}$ & $\begin{array}{l}\text { Ferraro et al., 2015; } \\
\text { Leifer, 1991; Padgett \& } \\
\text { Ansell, 1993 }\end{array}$ \\
\hline
\end{tabular}

